Epidemiology

\title{
Understanding food choices and eating practices of Brazilian and Spanish athletes in aesthetics and weight class sports
}

\author{
Claudia Ridel Juzwiak ${ }^{1}$ \\ ${ }^{1}$ Universidade Federal de São Paulo, Departamento de Ciências do Movimento Humano, Santos, \\ SP, Brazil.
}
Associate Editor: Danilo Rodrigues Pereira da Silva. Universidade Federal de Sergipe, São Cristóvão, SE, Brasil.

\begin{abstract}
Aim: This study aimed at understanding determinants of food choices and eating practices of aesthetics and weight class athletes from two countries. Methods: In this qualitative study, through recorded in-depth individual and focal group interviews, gymnasts $(n=16)$ and martial arts $(n=18)$ athletes from Brazil and Spain reported their eating practices. Transcripts were analyzed through the Content Analysis method. Results: The main determinants of athletes' eating practices were the quest for a specific body in line with each sports' discipline and cultural food aspects. The everyday eating practices respected the country of origin's food culture; however, some practices, especially aiming at weight loss were similar in both countries and related to the sports discipline. Female Brazilian aesthetics athletes were particularly worried about achieving a thinner body. Martial arts athletes from both countries reported adopting fast weight loss strategies presently or at some point in their sports trajectory. Internal and external pressure to lose weight was a constant factor, especially amongst Brazilians. Conclusions: There is a specific body culture in each sport discipline, which extends beyond country borders. The idealized bodies athletes seek are constructed socially according to their sports. This confers them an identity and promotes beliefs and meanings to foodways. The sportsrelated eating practices which superimposed national foodways were similar in both countries, suggesting a group identity process, and the existence of a "sports discipline's food culture". Understanding athletes' determinants of food choices and eating practices provide insights to address the gap between nutritional recommendations and eating practices.
\end{abstract}

Keywords diet, culture, body image, eating behavior.

\section{Introduction}

According to the state-of-the-art of sports recommendations, nutrition should be adjusted by taking into consideration athletes' individual aspects regarding health, energy and nutrient needs, physical characteristics, athletic goals, food preferences, and training periodization, as well as athlete's food availability and skills. When body mass loss is required, it should be programmed to occur in a specific training stage, far from the moment of competition, and focus on strategies that maximize body fat loss while preserving muscle mass (e.g., increasing dietary protein intake) and health (e.g., gradual body mass loss) ${ }^{1}$.

Despite presenting different physiological characteristics, aesthetics and martial arts sports have in common the constant concern of athletes with their body mass, although each sport with its specificities. Beauty is part of the nature of rhythmic (RG) and aesthetic (AG) gymnastics and it is expected to be seen in athletes' body (shape, dress, hairstyle, ornaments) and how they use it: discipline and chain of movements, the accuracy of gesture, symmetry, harmony, and timing to the music, the creativity of choreographies, nuances of movements, and use of physi- cal space. All these aspects will be valued for the score in competitions ${ }^{2}$. On the other hand, in martial arts and other combat sports, athletes are classified according to their body mass for competition, to create fairness between adversaries. This leads many athletes to reduce body mass to get a technical advantage by competing in a lower weight category than their usual body mass, against lighter and weaker opponents. The adoption of radical measures to 'cut weight' is a common practice among combat athletes, who adopt a variety of strategies which include continuous dieting, fasting, and dehydration strategies (i.e., reduced liquid intake, use of sauna, exercising using plastic suits, use of diuretics) $)^{3-6}$.

Literature shows that athletes involved in aesthetics and weight category sports of different ages, and countries, for the most part, do not consume adequate $\operatorname{diets}^{7-10}$. Cultural background, life trajectories, experiences, and athletic goals can create important barriers for the adoption of eating practices in line with precepts of a diet considered ideal for athletes, as well as to promote the adoption of practices that may affect negatively athletic performance and, more importantly, athletes' health ${ }^{5,11,12}$. 
Eating decisions represent a dynamic and complex process, dependent on several determinants associated with biological (e.g., hunger, taste, satiety), socio-cultural (e.g., family, and social networks, cultural norms), personal/psychological (e.g., knowledge, beliefs, eating experiences, cooking skills, convenience), and environmental (economic, informational, educational, political) aspects $^{13-15}$. Among athletes, knowledge about the importance of nutrition on performance, the type of sports practiced, the pursuit of athletic goals (ideal physique and body composition, performance results), level of participation (e.g., professional or amateur), and the influence of coaches are also important determinants of their food choices $^{11,14,16}$. How these determinants interact during the life of an individual, reflect his/her past and current experiences, and shape the thoughts, beliefs, and future actions related to eating ${ }^{13}$.

Few studies detail athletes' food choices and eating practices from a qualitative perspective $\mathrm{e}^{5,11,12,17-21}$. However, those available have brought valuable insights to expand the understanding about athletes' choices and practices as they investigate beyond what athletes eat, bringing reasons why and how athletes think and behave in relation to food. These are essential elements to develop nutrition education programs designed to meet the specific needs and demands of athletes/teams.

In this study, the objective was to understand determinants of food choices and eating practices of athletes in aesthetics and weight control sports from two countries.

\section{Methods}

This qualitative study is part of the research "Athlete Food Intake: Construction of an Athletic Food Culture", which aimed to understand how the food selection process of athletes of different countries and sports disciplines happens. The focus of this manuscript is on aesthetics and martial arts athletes who share a concern for body weight control. The Ethics Committee of the Universidade Federal de São Paulo approved this study under appraisal $\# 1.009 .373 / 2015$, and a written consent was obtained from all participants or those responsible for them, in the case of athletes under 18 years of age.

\section{Participants}

Convenience sampling ${ }^{22}$ was used to recruit athletes, through face-to-face contact with competing teams. Athletes who met the inclusion criteria were invited to participate. In Spain, in a snowball sampling design ${ }^{22}$, the initial participants nominated other potential teams or athletes who met the criteria to participate in the study. The inclusion criteria were to be at least 15 years old, to train for at least 5 hours/week, and to regularly compete (respecting the competition calendar of the sports disciplines). Athletes living in high-performance centers were not inclu- ded, as they live, as far as food provision is concerned, in an environment with controlled nutritional conditions. Athletes could be of either sex, and different ages, competing at various levels, and therefore, intentionally representing a diversity of subjects.

Male and female Brazilian $(n=16)$ and Spanish ( $\mathrm{n}=18$ ) athletes from aesthetics (rhythmic, aesthetic, and artistic gymnastic - GYM) and weight class (martial arts: judo and karate - MA) sports participated in this study, totaling $16 \mathrm{GYM}$ and $18 \mathrm{MA}$ athletes. Brazilian athletes belonged to teams of a city in the state of São Paulo, while Spanish athletes represented teams from the Barcelona area. Eight Brazilian and 10 Spanish athletes were involved in international competitions. All competed in national and regional events.

The different cultural characteristics of both countries were key to understand if body perception and food practices differed among athletes from the same sport but from different origins. Table 1 summarizes the athletes' characteristics.

\section{Procedures}

The Food Choice Process Model ${ }^{13}$ was adopted as the theoretical framework to build an open-ended questionnaire. This model was created from a social constructivist methodology based on a grounded theory and presents interrelated determinants of food choice grouped into three main components: life course, influences, and personal system ${ }^{13}$. Other sports nutrition studies adopted this model ${ }^{12,18}$. A semi-structured interview guide with predominately open-ended questions was developed. Also, follow-up and probing questions were asked when necessary, to explore and clarify issues or complement information (Table 2). The interview guide was pilot tested with three athletes, who were not included in the study, to assess the acceptability and comprehension by the interviewees. No changes were necessary for the interviewing guide after the pilot tests.

Table 1 - Characteristics of gymnastics and martial arts athletes.

\begin{tabular}{|c|c|c|c|c|}
\hline & \multicolumn{2}{|c|}{ Gymnastics (GYM) } & \multicolumn{2}{|c|}{ Martial Arts (MA) } \\
\hline & BR & ES & BR & ES \\
\hline & $n=8$ & $n=8$ & $n=8$ & $n=10$ \\
\hline \multirow[t]{2}{*}{ Age (years) } & $21.8(4.1)$ & $19.9(3.8)$ & $23.9(4.3)$ & $27.6(8.7)$ \\
\hline & [18-31] & {$[15-26]$} & {$[18-30]$} & [19-42] \\
\hline \multirow[t]{2}{*}{ Time in sport (years) } & $8.6(5.9)$ & $14.0(5.5)$ & $12.8(3.9)$ & $19.0(11.0)$ \\
\hline & {$[5-23]$} & {$[7-22]$} & {$[7-18]$} & [4-37] \\
\hline \multirow[t]{2}{*}{ Training (hours/week) } & $16.4(5.6)$ & $12.2(5.9)$ & $15(2.7)$ & $10.5(2.8)$ \\
\hline & {$[6-20]$} & {$[7.5-20]$} & {$[10-20]$} & {$[6-15]$} \\
\hline
\end{tabular}

$\mathrm{BR}=$ Brazil; ES $=$ Spain. Results are shown as mean and standard deviation (between parenthesis). Minimum and maximum values are between the brackets. 
Table 2 - Guiding and probing questions and clues

\begin{tabular}{|c|c|}
\hline Guiding questions & Probing questions and clues \\
\hline $\begin{array}{l}\text { How was your entry into a competitive } \\
\text { sport? }\end{array}$ & Explore life trajectory and sports trajectory. \\
\hline $\begin{array}{l}\text { How becoming an athlete affected your } \\
\text { diet? }\end{array}$ & Explore how the diet was and how it changed after becoming an athlete. \\
\hline $\begin{array}{l}\text { What do you consider an adequate diet for } \\
\text { athletes? }\end{array}$ & $\begin{array}{l}\text { Explore barriers and facilitators to achieve it. Explore similarities and differences between definitions. } \\
\text { Explore cultural aspects. }\end{array}$ \\
\hline \multicolumn{2}{|l|}{ What do you consider a healthy diet? } \\
\hline How do you eat during the training phase? & $\begin{array}{l}\text { Explore the changes in habit according to periodization. Explore concerns with daily food (goals of weight } \\
\text { and body composition, body image issues, and cultural aspects of countries' food). Explore a typical day - } \\
\text { who do you eat with? Where do you eat? }\end{array}$ \\
\hline How do you eat in the competitive period? & $\begin{array}{l}\text { Explore reasons for the strategies adopted before, during, and after competitions. Explore defeat and victory. } \\
\text { Explore food, drink, supplement, or traditions that are adopted thinking about the competition's results. }\end{array}$ \\
\hline How do you plan your meals? & Explore the chain of thought. \\
\hline $\begin{array}{l}\text { How is food on weekends and/or off- sea- } \\
\text { son? }\end{array}$ & $\begin{array}{l}\text { Identify the main changes in relation to the usual dietary pattern. Explore the chain of thought and cultural } \\
\text { issues. }\end{array}$ \\
\hline $\begin{array}{l}\text { How do the people around you influence } \\
\text { the way you eat? }\end{array}$ & $\begin{array}{l}\text { What do you think of what others eat (family, friends, coaches)? Explore situations of commensality with } \\
\text { different groups }\end{array}$ \\
\hline
\end{tabular}

Thirty-one athletes were individually interviewed. Three Spanish gymnasts accepted to participate only in the focus group, totaling 34 athletes. Three focus groups were formed: four female Spanish aesthetic gymnasts; three male Spanish karate athletes, and three female Brazilian rhythm gymnasts.

Interviews and focus groups took place on-site at training facilities or at place and time of the athletes' convenience, in Portuguese in Brazil, and in Spanish in Spain. The selected excerpts from the interviews were translated into English by the author, respecting to the maximum the idiomatic expressions and slang used by the athletes. Regarding the research team and reflexivity ${ }^{23}$, in Spain, all individual interviews and focus groups were carried out by the author, who had no previous relationship with the athletes. In Brazil, the author had had previous contact with some of the athletes through a Nutrition Education project offered to the city's athletic community by the University, and an interviewing team was formed. It was composed of four undergraduate students, and two nutrition Ph.D. professors (the author and a colleague), who were fully trained before initiating data collection. Interviews were conducted by two members of the interviewing team.

Interviews were scheduled until saturation was achieved, that is, narratives became redundant and no new insights were provided by the athletes ${ }^{22,24}$. The recording of the interviews yielded a total of $18 \mathrm{~h} 01$ ' 51 ', which were transcribed verbatim. Field notes were taken after each interview/focal group. The triangulation method (individual interviews, focal groups, and field notes) was used to enrich and complement each other, leading to a better understanding of the phenomena ${ }^{22}$.

Transcripts were analyzed using the thematic Content Analysis method ${ }^{24}$, "to systematically organize data into a structured format (p. 351)"23. First, transcripts were read and coded solely and manually by the author. A priori codes were defined based on the components of the Food Choice Process Model ${ }^{13}$. After the exhausting reading of the transcriptions, further codes emerged from the subjects' discourses. Context units from the athletes' discourses were identified for each code. Codes were then organized and systematized into three thematic nuclei, which will be explored in the results section. Finally, inferences were produced allowing the interpretation of the results taking into consideration the events reported in time, context, and meanings ${ }^{24}$, having as a framework for the understanding of the determinants of athletes' food choices the Food Choice Process Mode ${ }^{13}$ and the Theory of Social Representations ${ }^{25}$. From these references ${ }^{13,25}$ it was possible to understand the mental processes used by athletes in the construction of their food choices and how they managed their decision process. Understanding how athletes think about food and how their conceptions influence their eating behavior, both in their objective (what, how much) and subjective (why) aspects, as well as their habitual and unconscious eating practices, brings valuable information on meaning and representations of food ${ }^{13,25}$.

\section{Results}

Three thematic nuclei emerged as results for analysis: "perceptions about the athletic body", "everyday food practices", and "eating to win". Although athletes represented a heterogeneous group as they had a wide age range, their narratives converged in many aspects.

\section{Perceptions about the athletic body}

All athletes interviewed initiated their participation in the sport at an early age (between 3 and 10 years old). 
They have, therefore, been exposed to the idea of the bodies desired for their elected sport throughout childhood and adolescence, moments of intense and complex transformations and emotional development.

GYM athletes from both countries reported controlling their weight presently, being concerned with their shape, the body "design", which reflects the requirements of the expected sports and are implicitly valued in competitions: a body "aesthetically thin to the look". All Brazilian GYM, both men and women, reported greater dissatisfaction with their bodies when compared to the Spaniards, reflecting both internal and external pressure, especially from coaches.

Despite the need for developed muscles for good performance, male artistic gymnasts also have concerns about weight control, for fear of injury but also due to aesthetics.

"...[The coach] nags saying: - Ah, you are chubby ... when I put on weight it's very easy to notice because it's just in that belly area... like, you know, on the side, on this region here...(GYM7, $21 \mathrm{y}$, male, BR)

Among the MA athletes their only concern is to reach the category weight in which they fight - what matters to them is the weight value $(\mathrm{kg})$ on the scale.

"When I have competition, say in March, in January I start to lead a life aiming to maintain weight, and generate the conditions to reach the $70 \mathrm{~kg}$ or the closest to $70 \mathrm{~kg}$ " (MA14, 22y, male, ES).

Brazilian athletes from both sports were more explicit about the need for weight control, while most Spaniards indicated that weight control was not a problem. However, throughout the interview, they reported several situations in which they adopted strategies to reduce their weight. Weight awareness was stronger among athletes involved in higher level of competition.

\section{Everyday food practices}

As the initiation in sports occurred at early ages in both countries, athletes had difficulty in identifying at which moment being an athlete started to determine changes in their ways of eating. Throughout the process, they were influenced first by their families and then by their coaches. The latter were particularly important among gymnasts, and especially amongst Brazilians.

\footnotetext{
"There was a time when my coach, was like: - 'You have to weigh 15 kilos less than your height', ...we were always weighed and if you gained weight, you had to stay after the end of the training and do a session of rope jumping" (GYM1, 21y, female, $\mathrm{BR})$.
}

In their daily diet athletes maintain a pattern with the typical characteristics of the food culture of their countries $^{26,27}$. For example, in both countries, lunch is the main meal. For Brazilians, the everyday staple food is the combination of rice and beans, with some type of meat and salad, eaten as one combined dish. In Spain, the typical meal structure includes a first dish, a second dish, and dessert. The first dish usually consists of legumes, pasta, vegetables, or rice preparations, while the second dish is usually a cut of meat. Lunch will be eaten around noon in Brazil, while in Spain, 2 pm is still considered lunch time. As a similarity, studies indicate that in both countries most people report eating 3-4 meals/day (usually breakfast, lunch, diner, and afternoon snack $)^{26}$.

In both countries, it was observed that when talking about performance, there is a shift in athletes' discourses as they "nutritionalize" their speeches, and instead of food/ingredients, they talk about the need to improve nutrients intake (i.e., to increase protein and carbohydrate intakes and to reduce fats).

"From the point of view of karate... to eat carbohydrates or a very energetic substrate before training and eating something rich in proteins after training to increase muscle mass and get stronger" (MA11, 20y, male, ES).

Regardless of the country, age, or sport, for many athletes a diet considered as healthy is also what they consider as adequate to guarantee their athletic performance. However, the concept of 'healthy eating' was different in both countries. For Brazilians, to achieve "healthy eating" the most important factors were to eat every 3-hours, to increase the intake of fruits and vegetables and wholegrain foods, while in Spain, athletes pointed out as healthy to have a varied diet, to increase the intake of fish and legumes. However, in both countries, regardless of the sports discipline, the concept of healthy eating coincided with the identification of foods that should be excluded from the athlete's diet: pastries, sweets, chocolates, chips, cream-filled cookies, soda, fried foods, greasy and fast foods.

For most athletes, especially Brazilians, the concept of a diet considered appropriate for an athlete is related to the need for strict control, also expressed with expressions such as "eating properly", "discipline", and "diet with rules", as there is a constant concern with body image and/ or weight loss. This represents a dichotomous discourse indicating a gap between the practices they adopt for weight control (i.e., restriction of food or food groups) and what they conceive as an adequate diet for optimal health (i.e., varied diet). For example, a female Brazilian judo player described an optimal diet, but then reports what she eats:

\footnotetext{
"[A healthy diet has] lots of fruit, vegetables, but everything controlled, not too much, but not too little ... Carbohydrates, that we consume a lot, but I know it has to be whole [grain], right? Because the body absorbs it better...Chicken, beef, fish... and supplements too. Athletes spend more, but at the same time, it must be controlled, right? Especially in judo, right? Because of this deals with the weight..."(MA4, 22y, female, BR).
}

"I eat a lot of junk food, I like to eat junk food, right? And I like to eat a lot too ... and I know it's wrong ... sometimes it is not 
junk food, it's eating the wrong things at the wrong time... To be honest, (the concern with weight) is greater when there's competition" (MA4, 22y, female, BR).

Some athletes highlighted some specific aspects associating nutrition and performance improvement: the importance of adapting energy to the demands of sport and the adjustment of nutrients. Brazilian MA athletes gave especial importance to supplements, consuming mainly protein-substances, especially whey protein. The main reasons for taking these supplements were associated with muscle mass gain.

Many athletes adopted some eating strategies (e.g., increased meal frequency but with lesser quantity of food; avoidance of fatty and junk foods) in their daily life, as they associated "dietary control" with the concept that they have as a "proper diet for athletes". More rigorous and restricted strategies were observed among Brazilian athletes.

"I was always a little overweight, so I used to follow crazy diets... it's the 'half diet', I ate half cereal bar at the beginning of the training at $2 \mathrm{pm}$, and the other half in the middle of the training at $6 \mathrm{pm}$, trained until $9 \mathrm{pm}$... I was very thin, I had 5\% (body fat), then I stopped menstruating... I had these problems, then I went back to normal" (GYM8, 18y, female, BR).

Two Brazilian MA athletes opted to follow a particularly strict weight control diet based on chicken, vegetables, and a controlled amount of carbohydrate as their daily routine, avoiding extreme practices before competition:

"[...] I saw others taking diuretics, purgatives, not eating, not drinking, vomiting. So, I did it all. But I felt bad, I had cramps. I decided to have a life with norms, more boring, but better. I eat chicken, broccoli, and salad. All my food is focused on my weight. If I want to eat a bit more I say: no, I can't. Otherwise, I'll have to go back to restricting my diet to cut weight before competitions" (MA7, 19y, female, BR).

Athletes who opted to adopt restricted diets deviate from their usual cultural food pattern: in Brazil, for example, the traditional rice and beans, the staple combination is eaten for lunch and dinner, is avoided. However, which foods and how restrictive the diet is varied among athletes. The lower concern about weight loss of the Spaniards generated fewer everyday restrictive practices.

At times, when athletes relax their diets (weekends, vacations, and eventually after competitions, as a reward, both when they lose or win), they consider it a lack of control over food, which causes them to feel guilty. Frequently participation in family and friend's reunions is hindered by food restrictions.

\section{Eating to win}

MA athletes, both Brazilians, and Spaniards, were concerned about eating, particularly aiming at weight loss, in the pre-competition period (defined as anywhere between one to four weeks before the competition although one Spanish karate athlete considered it as a three months period). Even among athletes who did not follow restrictive diets for weight control in their everyday lives, during this period, they seek to adjust their weight to the weight category in which they fight.

Out of the MA athletes interviewed, all Brazilians and seven of the Spaniards adopt or adopted at some point in their sporting career fast weight loss practices. The diet modifications and other strategies adopted were dependent on how many kilograms they had to "cut". In this study, athletes reported that they needed to decrease between $1 \mathrm{~kg}$ and $6 \mathrm{~kg}$. Which steps they took to reach this weight depended on how long before the competition they started the process.

Strategies varied from reducing total food quantity and carbohydrate-rich foods, excluding soft drinks and fried foods, but maintaining their usual eating patterns, to adopting more drastic weight loss strategies (i.e., use of diuretics, sauna, fasting). These drastic strategies were reported by some athletes, from both countries, as being used during their adolescent years, when hormonal changes lead to intense growth and biological maturation, and when weight gain is expected. For some athletes, this was a moment of decision to change to categories with higher weight, in which they could maintain a more appropriate weight to their health and abandon the restrictive practices.

\footnotetext{
"I changed weight category at 17 (years old). It required more of me, but I felt better and trained better. It was a personal decision so as not to give up judo" (MA1, 25y, male, BR).
}

Two MA athletes reported cutting between $3 \mathrm{~kg}$ and $6 \mathrm{~kg}$ and adopting very restrictive and radical strategies (the most common: prolonged fasting and dehydration. Dehydration strategies included: decreased fluid intake, sweating achieved when exercising - often dressed in plastic or woolen clothes - or sauna, use of diuretics, laxatives, spitting, and chewing gum). Both athletes reported that sometimes weight cutting is achieved in the week before competitions, with a negative impact on performance. Even athletes who reported not having used radical strategies, know other athletes who have used those more aggressive conducts.

\footnotetext{
"The day before the competition I don't drink nor eat anything. Or I have breakfast and lunch at about $2 \mathrm{pm}$ and then I don't eat anything until weighing at $2 \mathrm{pm}$ the next day, so I stay $24 \mathrm{~h}$ without drinking and eating" (MA14, 22y, male ES).

"...the eve before the competition, I come to the gym and I run in a sweater, I go to the sauna ... I prefer to stop eating instead of exercising more ... In extreme cases, something I have not done in a long time, I take diuretics too, which is horrible, and I do not want to use it anymore ... It makes me feel dizzy, it "breaks you...then you feel cramps and you feel weak. It greatly impairs performance..." (MA4, 22y, female, BR)
} 
GYM athletes also reported food restrictions starting about a month before the competitions. Unlike the MA athletes, they did not refer to dehydration practices, fasting for long periods, or use of medications, focusing on reducing the amount of food consumed and avoiding foods considered to have a higher energy content. As well as among MA athletes, the greater the need to lose weight, the more restrictive the diet.

Both GYM and MA athletes, especially Brazilians, deprive (or deprived at some point in their trajectory) themselves of food that is pleasurable to them and their speeches are of sacrifice and internal and external pressure to reach the ideal body, they seem to rarely eat with pleasure, without feeling guilty.

\section{Discussion}

The main determinants of eating practices of athletes in aesthetics and weight control sports interviewed in this study were the quest for a specific idealized body according to sports' discipline, and cultural food aspects associated with their country of origin.

The results suggest that there is a specific body culture in each sport, which goes beyond country borders, in which the physical bodies that athletes look for are idealized and constructed as social bodies according to their sports discipline. This was particularly observed in the pre-competition phase when weight-loss strategies seem to be standardized according to sports groups and to deviate from their cultures of origin (family, country). Adopting these strategies promote beliefs and meanings to ways of eating as part of their identity of "being an athlete" The reported strategies in this study are found in the literature in studies conducted with athletes from different countries $^{3-5,28}$, suggesting a cultural sport globalized practice.

For instance, among combat athletes, Pettersson et al. ${ }^{5}$ identified that weight control mediated athletes' self-image giving them a sense of being "real athletes", reinforcing the idea of an association between body and sport identity.

On the other hand, among GYM there seems to be a mismatch between desired weight and desirable weight $^{29,30}$; that is, these athletes, especially female gymnasts, seem to always be dissatisfied with their bodies, always wanting to reach an even more perfect body, as observed from the athletes' speeches.

Both GYM and MA athletes in this study are concerned with weight control and caring for their bodies plays a great centrality in their lives ${ }^{3}$. However, in general, Brazilians adopted more restrictive and rigorous dietary strategies, coaches seem to be more influential among them, and among MA athletes, supplement use was more prevalent than among the Spaniards. It can be inferred that the level of competition (all Brazilian MA athletes partici- pated in international competitions) could explain the use of supplements, but social-cultural differences in body ${ }^{31}$ and sports culture and training environment ${ }^{32}$ of the country of origin should be taken into consideration when working with athletes.

The models of the female and male body to which athletes have been exposed since an early age when they started training, build their identity, and accompany them throughout life and sports careers, influencing their selfesteem $^{2,33}$ and their food practices ${ }^{14}$. For instance, in a study with German children (7-12 years old), the concern with weight was already present and girls were more concerned with weight and shape than boys, especially those involved in aesthetics sports ${ }^{34}$.

The strong self-imposition that leads them to adopt restrictive diets and a great effort to reach the desired and expected body model was also seen in other stu$\operatorname{dies}^{2,3,11,28-30}$. For both men and women, this search for stereotyped models creates dissatisfaction with their body images when they do not reach the models, increasing the risk of developing eating disorders ${ }^{36,37}$.

As regards the countries' food cultural aspects, in their everyday practices' athletes adapt what they consider as an adequate diet to the foods they recognize from their cultural upbringing and ingredients that are available locally. Brazil and Spain have quite different food cultures. Not only do ingredients differ, but also the social norms which structure eating practices, such as the dishes that make up a meal and the time of meals during the day $^{26,27}$. Although cultural food aspects of the countries permeate athletes' everyday eating practices, they can be superimposed by practices related to athletic goals, mainly observed in situations of weight control.

The most frequently consumed foods, meals, and mealtimes are in line with the food pattern consumed in both countries ${ }^{26,27,38}$. A study with British football players also found that they ate traditional British food at home, which they considered healthier, in contrast with food served at their clubs, more aligned with nutritional sports recommendations ${ }^{19}$.

However, the search for the ideal sports body impacts on the athletes' eating practices. For some of the athletes interviewed, eating is reported as a process of sacrifice, constant control. It suggests a constant struggle with their bodies, that is, a continuous competition with themselves, which is more complex than the competition against their opponents. However, Porpino ${ }^{28}$ points out based on the reality of RG athletes that "the sacrifice is rewarded by significant aesthetic experience that is concretized in the moments of the competitions" and that "the pleasure of winning also fulfills the role of making sacrifices valid" (p. 128) ${ }^{28}$. Vaz ${ }^{35}$ also discusses the proximity between the sacrificial process of formation of the subject and what occurs in sport, which seems to corroborate what has been found in this study regarding athletes and their 
relationships with food and why they persist in their involvement in these sports.

The eating practices found among athletes from both countries are much more widespread than the nutritional guidelines proposed in the literature, suggesting a "sports discipline's food culture", that might be found in other countries as well.

Although this study brings relevant insights to understand determinants of weight/aesthetics sports athletes' food choices, some limitations deserve attention: participants do not reflect a representative sample of the Brazilian and Spanish athletic population. Interviews conducted by more than one interviewer in Brazil and conducted in a language (Spanish) that is not the interviewer's mother language increased the complexity of the data collection.

\section{Conclusions}

The highlight of this study, by adopting a qualitative approach, was to give athletes a voice to express the processes involved in their body perception, food choices, and eating practices.

Despite the existing body of knowledge about sports nutrition, the body culture and certain eating practices remain linked to the sports discipline among GYM and MA athletes, going beyond country borders. Results suggest that the idealized bodies athletes seek are constructed socially according to their sports and that confers them an identity and promote beliefs and meanings to foodways as part of "being an athlete".

Their foodways reflect how conceptions, sports trajectory, sociocultural, emotional, and environmental factors influence their food choices and eating practices. Notwithstanding, the sports-related eating practices which superimposed national foodways were similar in both countries, suggesting a group identity process, and the existence of a sports discipline's food culture.

Nutritionists and other sports professionals working with athletes should develop skills to bridge the gap between all the cultural aspects identified and the nutritional recommendations and to develop nutrition education programs designed to meet the specific needs and demands of each athlete/team. Nutrition education programs for aesthetics and weight class athletes should have a special focus on body image perception and should include family and coaches. Athletes involved in sports where body mass control is desired should associate their eating practices not only with sports success but with health as well.

\section{Acknowledgments}

This study was supported by the Coordenação de Aperfeiçoamento de Pessoal de Nível Superior (Process grant:
BEX 6191/14-2). I thank Maria Fernanda Frutuoso RD, PhD; Marcia Coelho RD; Natalia Daniel RD, Ms.; Luana Jürgensen RD, Ms; and Anna Vitoria Oliveira RP, Ms. for their assistance.

\section{References}

1. American College of Sports Medicine, American Dietetic Association, Dietitians of Canada. Nutrition and Athletic Performance. Med Sci Sports \& Exerc. 2016;48(3):543-68. doi: 10.1249/MSS.000000000000085

2. Cavalcanti LMB, Porpino KO. O sofrimento e a dor como constituintes da beleza esportiva: reflexões para a educação. Holos. 2015;31(5):401-13. DOI: 10.15628/holos.2015.2556

3. Sundgot-Borgen J, Garthe I. Elite athlete in aesthetic and Olympic weight-class sports and the challenge of body weight and the use of composition. J Sports Science. 2011;29(S1):S101-14. DOI: 10.1080/ 02640414.2011 .565783

4. Franchini E, Brito CJ, Artioli, GG. Weight loss in combat sports: physiological, psychological and performance effects. J Int Soc Sports Nutr. 2012;9:e52. https://doi.org/ 10.1186/1550-2783-9-52

5. Pettersson S, Ekström MP, Berg CM. Practices of weight regulation among elite athletes in combat sports: a matter of mental advantage? J Athl Train. 2013;48(1):99-108. doi: 10.4085/1062-6050-48.1.04

6. Martinez Abellán A. Efectos de las pérdidas de peso y de la deshidratación en deportes de combate. Revista Euroamericana de Ciencias del Deporte. 2013;3(1):59-68.

7. Miteva S, Yanev I, Kolimechkov S, Petrov L, Mladenov L, Georgieva V, et al. Nutrition and body composition of elite rhythmic gymnasts from Bulgaria. International Journal of Sports Science \& Coaching. 2020;15(1):108-16. https://doi. org/10.1177/1747954119892803

8. Silva MP, Paiva T. Poor precompetitive sleep habits, nutrients' deficiencies, inappropriate body composition and athletic performance in elite gymnasts. Eur J Sport Sci. 2016;16(6):726-35. doi: 10.1080/17461391.2015.1103316

9. Mognol KB, Paixão MPCP. Perfil nutricional de adolescentes atletas de judô em períodos pré e pós-competições. Rev Bras Nutr Esportiva. 2017;11(63):339-52.

10. Ribas MR, Furtuoso CAZ, Emerick R, Ramon W, Cordeiro HJ, Bassan JC. Perfil dietético de atletas de karatê da seleção brasileira durante o período pré-competitivo. Rev Bras Nutr Esportiva. 2017;11(67 supl 1):826-35.

11. Pettersson S, Ekstrom MP, Berg CM. The food and the weight combat. A problematic fight for the elite combat sports athlete. Appetite. 2012;59:234-42. doi: 10.1016/j. appet.2012.05.007.

12. Smart LR, Bisogni CA. Personal food systems of male college hockey players. Appetite. 2001;37:57-70. doi: 10.1006/ appe. 2001.0408

13. Sobal J, Bisogni CA. Constructing food choices decisions. Ann Behav Med. 2009;38(suppl 1):S37-S46. DOI: 10.1007/ s12160-009-9124-5

14. Birkenhead KL, Slater G. A review of factors influencing athletes' food choices. Sports Med. 2015;45:1511-22. doi: $10.1007 / \mathrm{s} 40279-015-0372-1$ 
15. Leng $\mathrm{G}$ et al. The determinants of food choice. Proceed Nutr Soc. 2017;76:316-26. doi:10.1017/S002966511600286X

16. Pelly FE, Burkhart SJ, Dunn P. Factors influencing food choice of athletes at international competition events. Appetite. $\quad 2018 ; 121: 1738$. https://doi.org/10.1016/j. appet.2017.11.086

17. Sabino C, Luz MT, Carvalho MC. O fim da comida: suplementação alimentar e alimentação entre frequentadores assíduos de academias de musculação e fitness do Rio de Janeiro. História, Ciências, Saúde - Manguinhos. 2010;17 (2):343-56.

18. Long D, Perry C, Unruh SA, Lewis N, Stanek-Krogstand K. Food personal system of male collegiate football players: a grounded theory investigation. J Athl Train. 2011;46 (6):686-95. doi: 10.4085/1062-6050-46.6.688

19. Ono M, Kennedy E, Reeves S, Cronin L. Nutrition and culture in professional football. A mixed-method approach. Appetite. 2012;58:98-104. doi: 10.1016/j.appet.2011.10.007

20. Busanich R, McGannon KR, Schinke RJ. Expanding understandings on the body, food, and exercise relationship in distance runners: a narrative approach. Psychol Sport Exerc. 2012;13:582-90. https://doi.org/10.1016/j.psy chsport.2012.03.005

21. Stokes EG, Hughes R, Shaw DM, O'Connor HT. Perception and determinants of eating for health and performance in high-level male adolescent rugby union players. Sports. 2018;6(49). http://doi:10.3390/sports6020049

22. Given LM (ed). The Sage encyclopedia of qualitative research methods. Thousand Oaks, Ca: Sage Publications, 2008.

23. Tong A, Sainsbury P, Craig, J. Consolidated criteria for reporting qualitative research (COREQ): a 32-item checklist for interviews and focus groups. International Journal for Quality in Health Care. 2007;19(6):349-57. DOI 10.1093/ intqhe/mzm042

24. Minayo MCS. O desafio do conhecimento. São Paulo: Hucitec; 2012.

25. Moscovici S. Notes towards a description of social representations. Eur J Social Psych. 1988;18:211-50.

26. Contreras J, Gracia M. Preferencias y consumos alimentarios: entre el placer, la conveniencia y la salud. In: Díaz C, Gómez C. Alimentación, consumo y salud. Colección de Estudios Sociales $\mathrm{n}^{\circ} 24$. Barcelona: Fundación La Caixa; 2008:153-88.

27. Barbosa L. Feijão com arroz e arroz com feijão: O Brasil no prato dos brasileiros. Horizontes Antropológicos. 2007;28:87-116.

28. Porpino KO. Treinamento de ginástica rítmica: reflexões estéticas. Rev Bras Ciênc Esporte. 2004; 26(1):121-33.

29. Krane V, Waldron J, Michalenok J, Stiles-Shipley J. Body image concerns in female exercisers and athletes: A feminist cultural studies perspective. Women Sport \& Phys Activity J. 2001;10(1):17-54. DOI: 10.1123/wspaj.10.1.17

30. Espeitx E. Práctica deportiva, alimentación y construcción del cuerpo. Rev Dialectología y Tradiciones Populares.
2006;LXI(2):79-90.

https://doi.org/10.22201/cim sur.18704115e.2006.2.244

31. Medeiros F. A "invisível” ditadura da beleza no Brasil: uma questão etnocêntrica. Revista Antropología del cuerpo. 2015;0:38-50.

32. Fortes LS, Ferreira MEC, Oliveira SMF, Cyrino ES, Almeida SS. A socio-sports model of disordered eating among Brazilian male athletes. Appetite. 2015;92(1):29-35. http://dx.doi.org/10.1016/j.appet.2015.05.005

33. Gastaldo EL, Braga AA. Corporeidade, esporte e identidade masculina. Rev Estudos Femininos. 2012;19(3):875-93. https://doi.org/10.1590/S0104-026X2011000300012

34. Grimminger-Seidensticker E, Möhwald A, Korte J, Trojan J. Body dissatisfaction in normal-weight children - sports activities and motives for engaging in sports. Eur J Sport Sci. 2018;18(7):1013-21. https://doi.org/10.1080/ 17461391.2018 .1473498

35. Vaz AF. Treinar o corpo, dominar a natureza: notas para uma análise do esporte com base no treinamento corporal. Cadernos Cedes. 1999;19(48):89-108. DOI: 10.1590/ S0101-32621999000100006

36. Neves CM, Meireles JFF, Carvalho PHB, Schubring A, Barker-Ruchti N, Ferreira MEC. Body dissatisfaction in women's artistic gymnastics: A longitudinal study of psychosocial indicators. J Sports Sci. 2017;(35)17:1745-51. DOI: $10.1080 / 02640414.2016 .1235794$

37. Taheri M, Irandoust K, Razipoor M. The study of eating disorders and body image among elite martial arts. Int $\mathrm{J}$ Med Res Health Sci, 2017; 6(11):108-12.

38. Úbeda N, Palacios Gil-Antuñano, N, Montalvo Zenarruzabeitia Z, García Juan B, García A, Iglesias-Gutiérrez E. Hábitos alimenticios y composición corporal de deportistas españoles de élite pertenecientes a disciplinas de combate. Nutr Hosp. 2010;25:414-21. DOI:10.3305/ nh.2010.25.3.4351

\section{Corresponding author}

Claudia Ridel Juzwiak, Universidade Federal de São Paulo, Departamento de Ciências do Movimento Humano, Rua Silva Jardim, 136, sala 302. CEP 11015-020, Santos, SP, Brasil.

E-mail: claudia.juzwiak@unifesp.br.

Manuscript received on November 12, 2020

Manuscript accepted on February 22, 2021

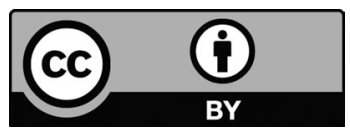

Motriz. The Journal of Physical Education. UNESP. Rio Claro, SP, Brazil - eISSN: 1980-6574 - under a license Creative Commons - Version 4.0 